\title{
Mechanism of antibacterial activity of the white- rot fungus Hypholoma fasciculare colonizing wood
}

\author{
Wietse de Boer, Larissa B. Folman, Paulien J.A. Klein Gunnewiek, \\ Teresia Svensson, David Bastviken, Gunilla Öberg, José C. del Rio, and \\ Lynne Boddy
}

\begin{abstract}
In a previous study it was shown that the number of wood-inhabiting bacteria was drastically reduced after colonization of beech (Fagus sylvatica) wood blocks by the white-rot fungus Hypholoma fasciculare, or sulfur tuft (Folman et al. 2008). Here we report on the mechanisms of this fungal-induced antibacterial activity. Hypholoma fasciculare was allowed to invade beech and pine (Pinus sylvestris) wood blocks that had been precolonized by microorganisms from forest soil. The changes in the number of bacteria, fungal biomass, and fungal-related wood properties were followed for 23 weeks. Colonization by the fungus resulted in a rapid and large reduction in the number of bacteria (colony-forming units), which was already apparent after 4 weeks of incubation. The reduction in the number of bacteria coincided with fungal-induced acidification in both beech and pine wood blocks. No evidence was found for the involvement of toxic secondary metabolites or reactive oxygen species in the reduction of the number of bacteria. Additional experiments showed that the dominant bacteria present in the wood blocks were not able to grow under the acidic conditions $(\mathrm{pH} 3.5) \mathrm{created}$ by the fungus. Hence our research pointed at rapid acidification as the major factor causing reduction of wood-inhabiting bacteria upon colonization of wood by $H$. fasciculare.
\end{abstract}

Key words: white rot, antibacterial activity, acidification, lignocellulolytic enzymes, organic chlorine, pyrolysis.

Résumé : Une étude précédente a montré que le nombre de bactéries résidantes du bois était radicalement réduit à la suite d'une colonisation de blocs de hêtre européen (Fagus sylvatica) par le champignon de la pourriture blanche Hypholoma fasciculare, l'hypholome en touffe (Folman et al. 2008). Nous rapportons ici les mécanismes responsables de cette activité antibactérienne induite par le champignon. H. fasciculare a envahi des pièces de hêtre et de pin (Pinus sylvestris) qui avaient été colonisées préalablement par des microorganismes du sol forestier, et les changements dans la numération bactérienne, la biomasse fongique et les propriétés du bois reliées à l'invasion fongique ont été suivis pendant 23 semaines. La colonisation par le champignon a résulté en une réduction rapide et importante du nombre de bactéries (en unités de formation de colonies) qui étaient déjà apparentes après 4 semaines d'incubation. La réduction de la numération bactérienne coïncidait avec l'acidification induite par le champignon tant dans les blocs de hêtre que dans les blocs de pin. Aucune preuve n'a été obtenue de l'implication de métabolites secondaires toxiques ou d'espèces réactives d'oxygène dans la réduction du nombre de bactéries. Des expériences additionnelles ont montré que les bactéries dominantes présentes dans les blocs de bois ne pouvaient pousser en conditions acides ( $\mathrm{pH} \mathrm{3,5)} \mathrm{créées} \mathrm{par} \mathrm{le} \mathrm{champignon.} \mathrm{Ainsi,} \mathrm{notre} \mathrm{recherche} \mathrm{in-}$ dique que l'acidification rapide est un facteur majeur qui cause la réduction du nombre de bactéries résidantes du bois à la suite de la colonisation par $H$. fasciculare.

Mots-clés : pourriture blanche, activité antibactérienne, acidification, enzymes ligno-cellulolytiques, chlore organique, pyrolyse. [Traduit par la Rédaction]

\section{Introduction}

Saprotrophic white-rot fungi play an essential role in carbon cycling in forest ecosystems, as they are the only organisms that are able to substantially decompose lignin, an important structural component of wood making up 20\%$40 \%$ of wood dry mass (Schmidt 2006; Baldrian 2008). It is not only the lignin decomposition itself that is important for complete wood decay, but also the fact that lignin decompo-

Received 13 October 2009. Revision received 11 December 2009. Accepted 12 March 2010. Published on the NRC Research Press Web site at cjm.nrc.ca on 11 May 2010.

W. de Boer, ${ }^{1}$ L.B. Folman, and P.J.A. Klein Gunnewiek. Netherlands Institute of Ecology (NIOO-KNAW), Department of Microbial Ecology, Boterhoeksestraat 48, Heteren 6666 GA, Netherlands.

T. Svensson and D. Bastviken. Water and Environmental Studies, Department of Thematic Studies, Linköping University, Linköping 58183, Sweden.

G. Öberg. Institute for Resources, Environment, and Sustainability (IRES) and Soil, Water, and Environmental Laboratory (SWEL), The University of British Columbia, 429-2202 Main Mall, Vancouver, BC V6T 1Z4, Canada.

J.C. del Rio. Instituto de Recursos Naturales y Agrobiología de Sevilla, CSIC, P.O. Box 1052, Seville 41080, Spain.

L. Boddy. Cardiff School of Biosciences, Cardiff University, Biomedical Building, Museum Avenue, Cardiff, Wales CF10 3AX, UK.

${ }^{1}$ Corresponding author (e-mail: w.deboer@nioo.knaw.nl). 
sition gives access to cellulose that is masked by lignin and, consequently, protected from decay by cellulolytic microorganisms (Schwarze et al. 2000).

White-rot fungi often establish in rays of undecayed wood, where easy access to nonstructural nutrients contained in parenchyma cells is provided (Schmidt 2006). These nonstructural nutrients, together with easily accessible cellulose and hemicellulose, appear to be important for the initial establishment of the fungus. However, other wood-inhabiting microorganisms could compete for these compounds and might, consequently, have a negative impact on colonization of wood by white-rot fungi.

Opportunistic saprotrophic bacteria and yeasts are among the first microorganisms to colonize wood, and white-rot fungi are confronted with these when colonizing wood (De Boer and van der Wal 2008). In an earlier study we reported that 2 white-rot fungi, Hypholoma fasciculare and Resinicium bicolor, drastically reduced the number of woodinhabiting bacteria upon colonization (Folman et al. 2008). The reduction in the number of bacteria was apparent for both cultivable and, to a lesser extent, total bacteria, pointing at bacteriostatic and bactericidal effects by these fungi. Hence, the strategy that these white-rot fungi seem to employ during colonization of wood is to kill potential competitors for nutrients.

In the study of Folman et al. (2008), mechanisms of the antibacterial effects of $H$. fasciculare remained unclear, as quantification of bacteria was only performed at the end of a long (30-week) incubation period. Several mechanisms for the antibacterial effects of the white-rot fungi were proposed, such as acidification, production of reactive oxygen species, and production of toxic secondary metabolites. The aim of the current study was to investigate the mechanism of the antibacterial effect of a wood-colonizing white-rot fungus in more detail. We performed a time-course analysis of bacterial dynamics and changes in wood physicochemical properties and fungal enzyme activities during colonization of wood by $H$. fasciculare, or sulfur tuft, a saprotrophic, cord-forming basidiomycete that is abundant on the dead wood of deciduous trees in Europe and North America (Boddy 1999). The beech and pine wood blocks used had been precolonized by microorganisms from a forest soil. The effects of rapid acidification and extracts of wood colonized by $H$. fasciculare on selected bacteria in liquid culture were also examined.

\section{Materials and methods}

\section{Fungus}

A strain of $H$. fasciculare (isolated from a fruit body, Cardiff University Culture Collection) was maintained on $2 \%$ malt extract agar $(20 \mathrm{~g} / \mathrm{L}$ of malt extract (Oxoid, Basingstoke, UK), $20 \mathrm{~g} / \mathrm{L}$ of technical agar (J.T. Baker, Phillipsburg, N.J.)). Blocks $(2 \times 2 \times 1 \mathrm{~cm})$ were sawn from logs of freshly felled European beech (Fagus sylvatica L.) and Scots pine (Pinus sylvestris L.) and kept at $-18{ }^{\circ} \mathrm{C}$ until use. Prior to use, the blocks were autoclaved. To obtain fungal inoculum for the microcosm experiment, autoclaved blocks were placed on fresh fungal cultures on malt extract agar and incubated for 8 weeks at $20^{\circ} \mathrm{C}$ in the dark.

\section{Microcosms}

Soil used in the microcosm experiment consisted of a mixture of sieved $(<4 \mathrm{~mm})$ material from the organic and upper $5 \mathrm{~cm}$ mineral layer of deciduous forest, as described by Folman et al. (2008).

Soil microcosms were prepared by compacting $120 \mathrm{~g}$ of soil in vented $14 \mathrm{~cm}$ diameter polystyrene Petri dishes. Beech wood blocks colonized by $H$. fasciculare were placed in the centre of the dishes, and the fungus was allowed to grow over the surface of the soil for 4 weeks in the dark at $20{ }^{\circ} \mathrm{C}$. Five wood blocks $(2 \times 2 \times 1 \mathrm{~cm})$ of either beech or pine, precolonized by soil microorganisms, were placed on the mycelium of $H$. fasciculare extending over the soil surface in the dishes. Precolonized wood blocks had been obtained by burying autoclaved wood blocks for 1 month in forest soil (100 blocks/kg soil). Controls consisted of similar blocks placed in soil microcosms without $H$. fasciculare.

At the start of the experiment, and after 4, 8, 13, and 23 weeks of incubation, blocks were taken from the microcosms, and adhering soil and surface mycelium were removed. After weighing the blocks, the outer parts $(1 \mathrm{~mm})$ were removed using sterilized scalpels. The inner parts were fragmented into sawdust using a drill with a sterilized $18 \mathrm{~mm}$ triple-point bit. Subsamples of sawdust were directly used for analyses or stored at $-80{ }^{\circ} \mathrm{C}$. There were 5 replicates per sampling time and treatment.

\section{Quantification of wood-inhabiting microorganisms}

Determination of the number of bacteria in wood samples was done by plate counting. In a previous study it was shown that the counting technique used detected most $(>60 \%)$ of the microscopically enumerated bacteria that had colonized wood blocks from forest soil (Folman et al. 2008). Samples of $100 \mathrm{mg}$ of sawdust were transferred into $5 \mathrm{~mL}$ sterile polypropylene screw-cap tubes, and $4 \mathrm{~mL}$ of a salt solution $\left(0.25 \mathrm{~g} / \mathrm{L}\right.$ of $\left.\mathrm{KH}_{2} \mathrm{PO}_{4}\right)$ was added. The suspension was shaken for $1.5 \mathrm{~h}$ at maximum speed on a vortex at $5{ }^{\circ} \mathrm{C}$, ultrasonically shaken $(2 \times 30 \mathrm{~s})$, and finally again shaken for $30 \mathrm{~min}$ at maximum speed on a vortex. Appropriate dilutions were plated in duplicate on water-yeast agar buffered to $\mathrm{pH} 5$ with 2-( $N$-morpholino)ethanesulphonic acid (Folman et al. 2008). Plates were incubated at $20^{\circ} \mathrm{C}$ in the dark. Colonies were counted regularly for 3 weeks.

Ergosterol, a sterol in fungal cell membranes, was used to quantify fungal biomass. Ergosterol was extracted from wood in a mixture of cyclohexane and alkaline methanol using a modification of the method of Bååth (2001), as described by Van der Wal et al. (2007). The ergosterol content of the extracts was determined by high-performance liquid chromatography (De Ridder-Duine et al. 2006).

\section{Enzyme assays}

Activities of the following enzymes involved in decomposition of the lignocellulose complex of wood were measured: cellulase (endo-1,4- $\beta$-glucanase), hemicellulase (endo-1,4- $\beta$-xylanase), laccase, and manganese peroxidase. Enzymes were extracted from sawdust ( $1 \mathrm{~g})$ in milliQ water ( $4 \mathrm{~mL}$ ), as described by Van der Wal et al. (2007).

Cellulase and hemicellulase activities were determined by measuring the release of Remazol Brilliant Blue R from azo-carboxymethlycellulose and azo-xylan (Megazyme, 
Fig. 1. Changes in the number of colony-forming units of bacteria (A) and fungal biomass indicator ergosterol (B) in the interior of beech wood blocks that were precolonized by forest soil microorganisms for 1 month and subsequently inoculated (open circles) or not (closed circles) with the white-rot fungus Hypholoma fasciculare. Bars represent SD of the mean of 5 replicates.

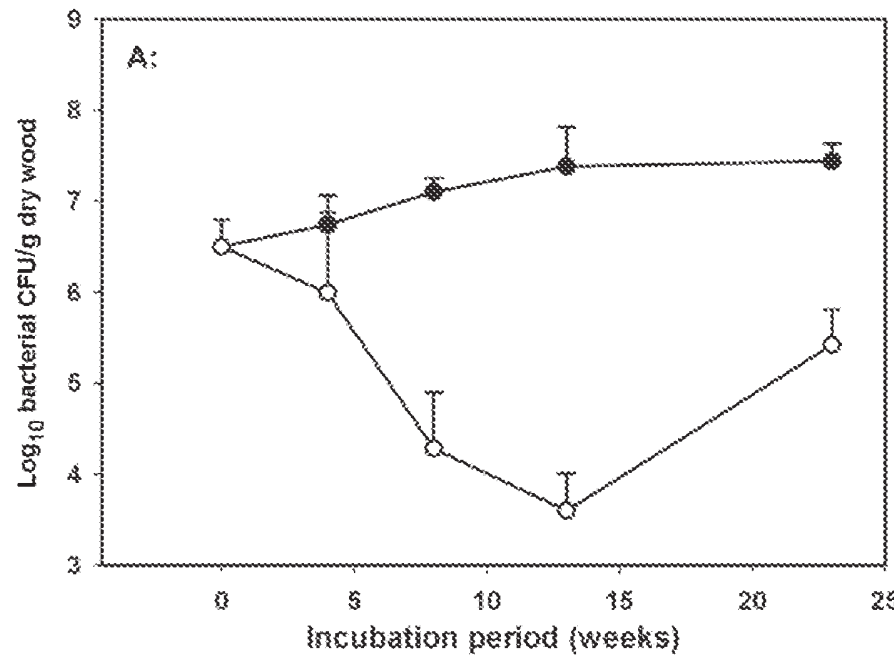

Bray, Ireland), respectively. Laccase activity was measured via oxidation of 2,2'-azinobis(3-ethylbenzthiazoline-6-sulfonate) (ABTS) (Bourbonnais and Paice 1990), and manganese peroxidase via the oxidative condensation reaction between 3-methyl-2-benzothiazolinone hydrazone (MBTH) and 3dimethylaminobenzoic acid (DMAB) (Daniel et al. 1994). Details of the procedures used are given by Van der Wal et al. (2007).

\section{Physicochemical analyses}

Gravimetric moisture content of wood was determined by mass loss of wood subsamples after $24 \mathrm{~h}$ at $70{ }^{\circ} \mathrm{C}$. $\mathrm{pH}$ of the wood was measured in the water extracts prepared for enzyme activity measurements.

The total amount of organically bound halides (referred to as organic chlorine, $\mathrm{Cl}_{\text {org }}$, since chlorine typically is the dominating halide) was analysed according to the TOX method (Asplund et al. 1994), in which $20 \mathrm{mg}$ of sawdust was shaken with an acidic nitrate solution to remove the chloride through ion exchange. The sawdust suspension was then filtered. After rinsing twice with acid nitrate solution, the filter and the retained sawdust was combusted at $1000{ }^{\circ} \mathrm{C}$ in a stream of oxygen. The hydrogen halides that formed were trapped and titrated in an electrolyte with silver ions.

Analytical pyrolysis coupled with gas chromatography mass spectrometry (GC-MS) was used to estimated the lignin/carbohydrate and the syringyl to guaiacyl $(\mathrm{S} / \mathrm{G})$ ratios. The pyrolysis of wood samples (approximately $1 \mathrm{mg}$ ) was performed in duplicate with a model 2020 microfurnace pyrolyzer (Frontier Laboratories Ltd., Yoriyama, Japan) directly connected to an Agilent 6890 GC-MS system (Agilent, Santa Clara, Calif.) equipped with a $30 \mathrm{~m} \times$ $0.25 \mathrm{~mm}$ i.d., $0.25 \mu \mathrm{m}$ DB-5MS fused silica capillary column. The detector consisted of an Agilent 5973 mass selective detector (electron ionization at $70 \mathrm{eV}$ ). The pyrolysis was performed at $500{ }^{\circ} \mathrm{C}$. The GC-MS conditions were as follows: the oven temperature was held at $50{ }^{\circ} \mathrm{C}$ for $1 \mathrm{~min}$ and then increased up to $100{ }^{\circ} \mathrm{C}$ at $30{ }^{\circ} \mathrm{C} / \mathrm{min}$, increased from 100 to $300{ }^{\circ} \mathrm{C}$ at $10{ }^{\circ} \mathrm{C} / \mathrm{min}$, and maintained at $300{ }^{\circ} \mathrm{C}$

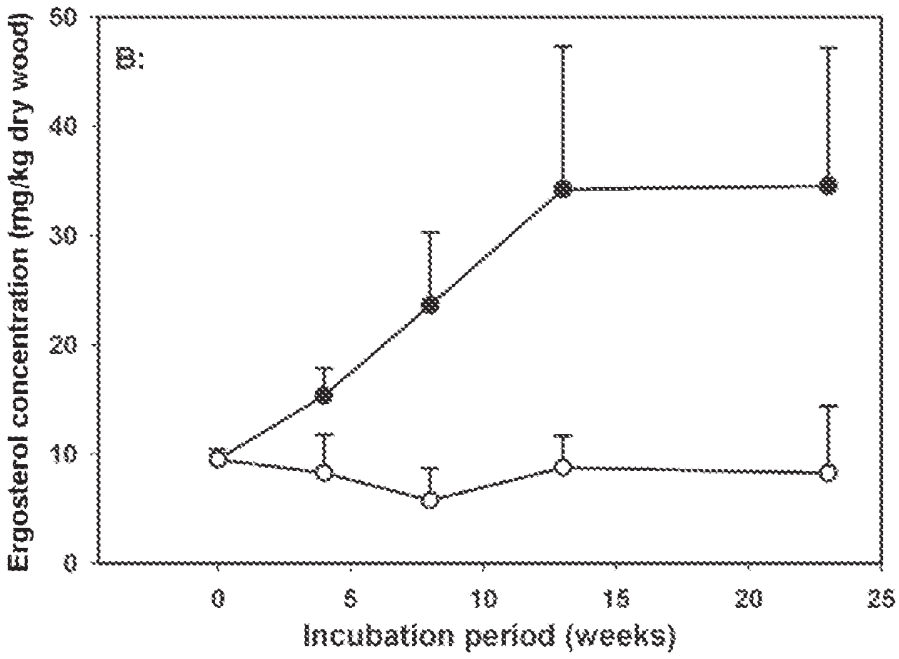

for $10 \mathrm{~min}$. The carrier gas used was helium, with a controlled flow of $1 \mathrm{~mL} / \mathrm{min}$. The compounds were identified by comparing the mass spectra obtained with those of the Wiley and NIST computer libraries and those reported in the literature (Faix et al. 1990; Ralph and Hatfield 1991). The relative lignin/carbohydrate ratio was estimated from the molar peak areas of the different carbohydrate and lignin compounds released by pyrolysis, while the $S / G$ ratio was estimated from the molar peaks areas of the different syringyl- and guaiacyl-derived lignin compounds.

Analyses of $\mathrm{Cl}_{\text {org }}$ and carbon compound composition were only performed for beech wood blocks.

\section{Effect of rapid acidification on the number of bacteria}

Possible sensitivity of wood-inhabiting bacteria to rapid acidification was tested by exposing bacterial colonizers of wood blocks to different $\mathrm{pH}$ values in liquid media. The wood blocks used had been incubated for 1 month in forest soil; hence, the bacteria present reflected those at $t=0$ of the time-course experiment. Bacteria were extracted from wood as described previously for plate counting, but with sterile tap water as extractant. Appropriate dilutions were added $(1 / 10)$ to a liquid growth medium $(3 \mathrm{~g} / \mathrm{L}$ of tryptone soya broth (TSB; Oxoid) in demineralized water) buffered to different $\mathrm{pH}$ values $(3.5,4.0,5.0$, or 6.0$)$ with a combination of 2-( $N$-morpholino)ethanesulphonic acid and citric acid or succinic acid $(10 \mathrm{mmol} / \mathrm{L})$. The inoculated growth media were incubated at $20{ }^{\circ} \mathrm{C}$ in darkness in 96-well microplates (well volume $0.2 \mathrm{~mL}$ ). All treatments (inoculum dilution $\times$ $\mathrm{pH} \times$ buffer composition) were performed in triplicate. During incubation the microplates were slightly shaken on a bench shaker. Growth of the bacteria was checked daily for 1 week by measuring the optical density at $600 \mathrm{~nm}$ using a microplate reader.

\section{Effect of extracts of wood colonized by $\boldsymbol{H}$. fasciculare on bacteria}

The possible presence of antibacterial water-soluble compounds in beech wood colonized by $H$. fasciculare was examined by growing 4 strains of wood-inhabiting bacteria in 
a mixture of growth medium and wood extract. Two Burkholderia strains (L630 and L721) and 2 Xanthomonas strains (L715 and L631) were selected from the collection of bacterial isolates obtained from beech wood blocks that were not colonized by a white-rot fungus (Folman et al. 2008). These strains are representative of wood-inhabiting bacteria that are likely to be most sensitive to activities of $H$. fasciculare, since they are dominant in the control treatment and decline strongly in the presence of the fungus $H$. fasciculare (Folman et al. 2008). The strains were pregrown at $20{ }^{\circ} \mathrm{C}$ in sterile liquid TSB broth (TSB at $3 \mathrm{~g} / \mathrm{L}, \mathrm{KH}_{2} \mathrm{PO}_{4}$ at $1 \mathrm{~g} / \mathrm{L}$, and $\mathrm{NaCl} 5 \mathrm{~g} / \mathrm{L}$, adjusted to $\mathrm{pH} 6.5$ ). The precultures were diluted $10^{3}-10^{5}$ times in fresh double-strength sterile TSB broth. Extracts were obtained from fresh sawdust, equivalent to $300 \mathrm{mg}$ dry mass, by sonication for $10 \mathrm{~min}$ and shaking for $2 \mathrm{~h}$ in $4.5 \mathrm{~mL}$ of sterile tap water followed by filtration over a $0.2 \mu \mathrm{m}$ polycarbonate filter. Equivalent amounts of wood extracts and diluted bacterial precultures were added to wells of microplates. Control treatments employed sterile water instead of wood extract. Incubation was at $20^{\circ} \mathrm{C}$ as described previously, and growth was monitored regularly by measuring the optical density at $600 \mathrm{~nm}$.

\section{Statistical analyses}

Differences in average values of microbiological, physiological, and physicochemical parameters between Hypholomacolonized and control wood blocks were tested for significance using one-way analysis of variance (ANOVA) followed by Tukey's honestly significant difference test at the $5 \%$ probability level. Before applying ANOVA, the assumption of normality was tested with the Shapiro-Wilk statistic, and the homogeneity of variance was tested with Levene's test. If necessary, $\log$ transformation was applied to satisfy the criteria of ANOVA. All statistical tests were performed using Statistica 7 (StatSoft Inc., Tulsa, Okla., USA).

\section{Results}

\section{Microbial colonization}

The interiors of both beech and pine wood blocks were colonized by bacteria after 4 weeks of preincubation in forest soil (Fig. 1A; Table 1). The number of cultivable bacteria was highest in the pine blocks. Colonization of both beech and pine wood blocks by $H$. fasciculare resulted in a rapid decrease of cultivable bacteria, with 1000 - to 10000 fold reduction in the number of bacteria by 13 weeks. In the control beech wood blocks, the number of cultivable bacteria gradually increased during incubation (Fig. 1A), whereas in the control pine wood blocks they remained fairly constant (data not shown).

Ergosterol increased in the control beech wood blocks, but not in those colonized by $H$. fasciculare (Fig. 1B). Ergosterol concentrations in pine wood blocks remained low during the whole incubation period for both the wood blocks colonized by $H$. fasciculare and the control treatments (data not shown).

\section{Physicochemical data}

Colonization by $H$. fasciculare resulted in a significantly $(P \leq 0.05)$ more rapid decay rate of beech wood than wood 
Fig. 2. Selected physical and chemical properties of the interior of beech wood blocks precolonized by forest soil microorganisms for 1 month and subsequently colonized (open circles) or not (closed circles) by the white-rot fungus Hypholoma fasciculare. (A) Dry mass loss, (B) $\mathrm{pH}$, (C) lignin/carbohydrate ratio, and (D) organic chloride content of the wood blocks during 23 weeks of incubation. Bars represent SD of the mean of 5 replicates.
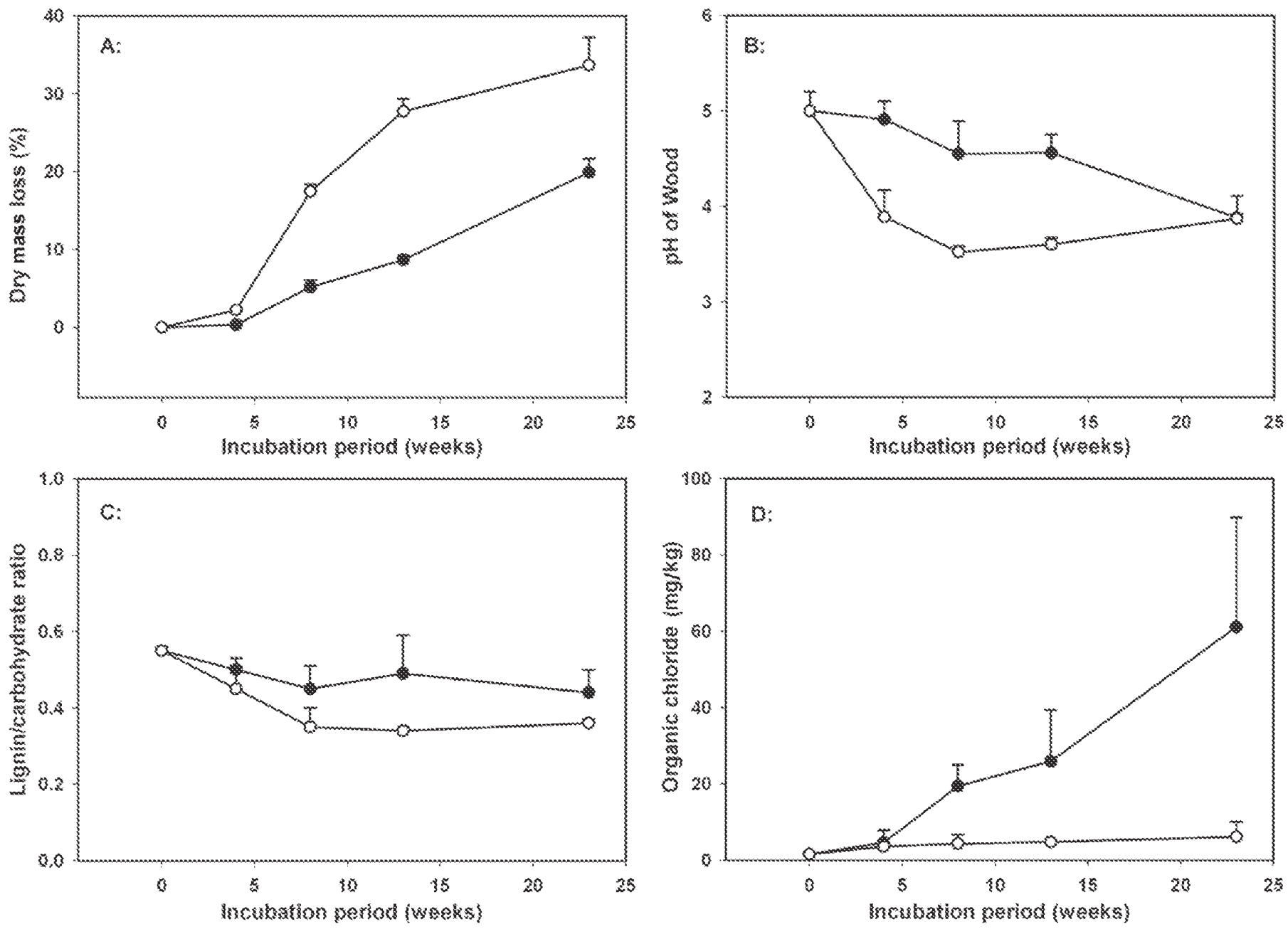

colonized by other soil microorganisms (Fig. 2A; Table 1). However, the decay rate of pine was significantly $(P \leq$ $0.05)$ less than that of beech. In addition, the decay rate of beech by other soilborne microorganisms was significantly $(P \leq 0.05)$ greater than that of pine by $H$. fasciculare.

Beech wood blocks rapidly acidified during the first 7 weeks after colonization by $H$. fasciculare, but by 23 weeks the controls had dropped to similar values below pH 4 (Fig. 2B). Despite the low wood-decaying activities of $H$. fasciculare in pine, its presence resulted in a $\mathrm{pH}$ decrease comparable to that in beech (Table 1).

The lignin/carbohydrate ratio showed slightly lower levels in Hypholoma-inoculated beech than in the controls (Fig. 2C), indicating a small and preferential degradation of the lignin moiety. The $\mathrm{S} / \mathrm{G}$ ratio, on the other hand, was about 2 during the whole incubation period for both Hypholoma-inoculated and control beech, and it was not much modified during the treatment (data not shown).

The concentration of $\mathrm{Cl}_{\text {org }}$ increased significantly in both the Hypholoma-inoculated beech blocks and the control blocks, but the increase in the control blocks was 10 times larger (Fig. 2D).

\section{Lignocellulolytic enzyme activities}

Cellulase activity in extracts from wood colonized by $H$. fasciculare increased considerably over the first 13 weeks and then dropped to half the maximum value (Fig. 3A). Cellulase activity in the control blocks increased throughout this period, but was significantly $(P \leq 0.05)$ lower than in wood colonized by $H$. fasciculare. Hemicellulase activity in wood colonized by $H$. fasciculare showed a similar response to cellulase activity, but the variation between replicates was larger and at 23 weeks had dropped to almost zero (Fig. 3B). In the control wood blocks, hemicellulase activity was low throughout the whole period. Both cellulase and hemicellulase activities were below the detection limit in Hypholoma-colonized and control pine wood blocks (data not shown).

Laccase activity remained low in beech wood blocks colonized by $H$. fasciculare (Fig. 3C). In control wood blocks, however, laccase activity was significantly higher $(P \leq 0.05)$ at some time points, although variation between replicates was high (Fig. 3C). No laccase activity was detected in pine (Table 1).

Manganese peroxidase activity rapidly increased in beech 
Fig. 3. Activities of wood-degrading enzymes in the interior of beech wood blocks that were precolonized by forest soil microorganisms for 1 month and subsequently inoculated (open circles) or not (closed circles) with the white-rot fungus Hypholoma fasciculare. Shown are the activities of cellulase (A), hemicellulase (B), laccase (C), and manganese peroxidase (D) in the wood blocks during a 23-week incubation period. Bars represent SD of the mean of 5 replicates.
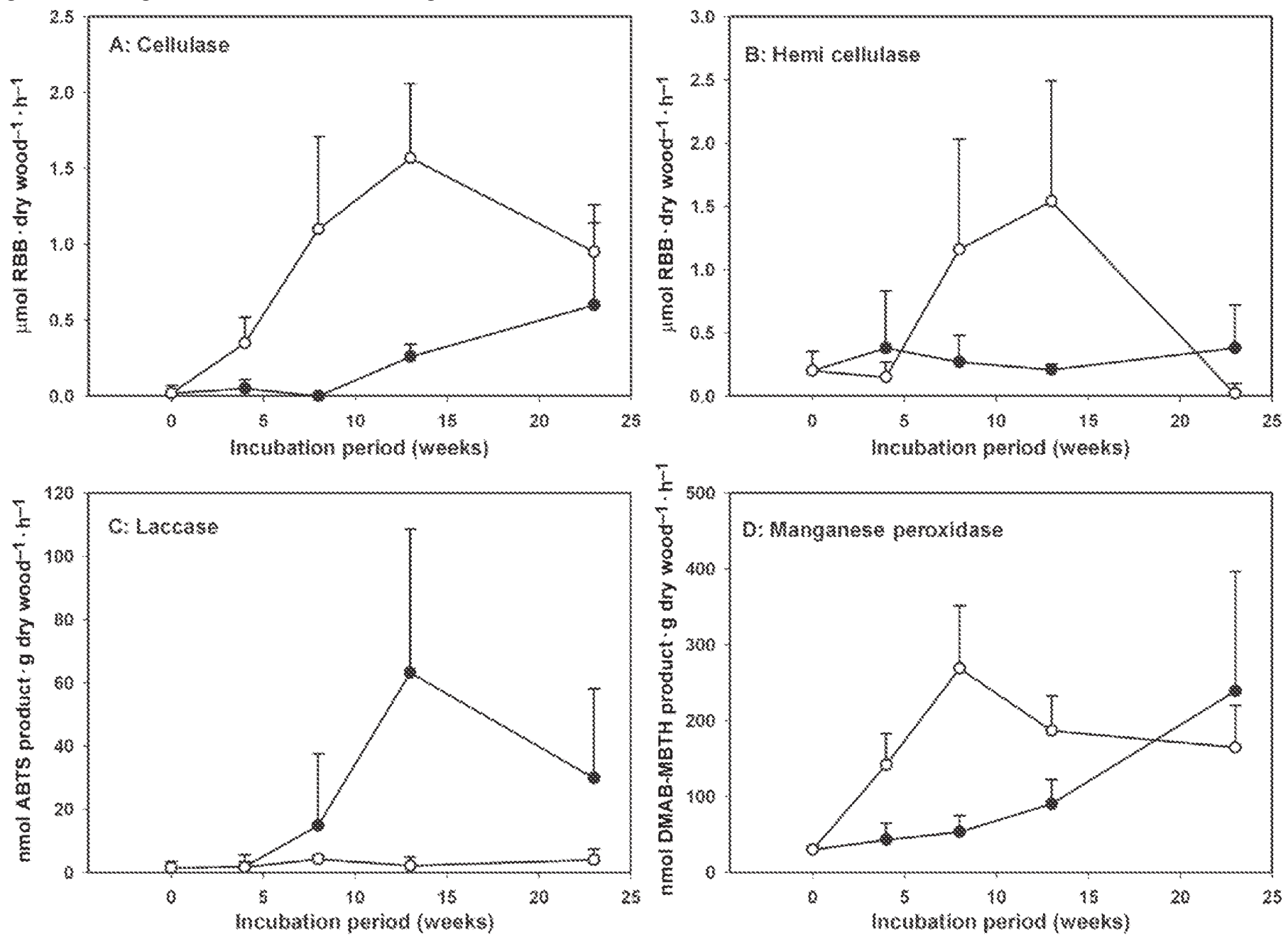

wood blocks colonized by $H$. fasciculare and remained high during the whole incubation period (Fig. 3D). In controls, there was a gradual increase of manganese peroxidase to levels similar to that of the wood colonized by $\mathrm{H}$. fasciculare by 23 weeks. There was also a rapid increase in manganese peroxidase activity in pine colonized by $H$. fasciculare, although the level of activity remained much lower than that in the beech (Table 1).

\section{Effect of rapid acidification on bacterial numbers}

There was rapid growth of bacteria in liquid media at $\mathrm{pH} 6.0$, to which $10^{-1}-10^{-3}$ dilutions of water extracts of buried wood blocks had been added. The results of the highest dilutions $\left(10^{-3}\right)$ containing the most abundant woodinhabiting bacteria are presented in more detail. Growth of the dominant wood-colonizing bacteria was dramatically reduced in the most acidic ( $\mathrm{pH} 3.5$ ) liquid media buffered both with citrate and succinate (Fig. 4). After 1 week, the optical density of inoculated wells containing media at pH 3.5 was not significantly $(P>0.05)$ different from that at the start of the inoculation, whereas optical densities at higher $\mathrm{pH}$ values (except $\mathrm{pH}$ in succinate-buffered medium) were signifi-

cantly $(P \leq 0.05)$ increased (Fig. 4). The apparent lack of growth continued during prolonged incubation ( 2 weeks) in the succinate medium, whereas there was variation (replicates with and without growth) in the citrate medium (data not shown). Lower dilutions $\left(10^{-1}\right.$ and $\left.10^{-2}\right)$ of wood extract contained bacteria that could grow at $\mathrm{pH} 3.5$ in both media without much delay (data not shown).

\section{Effect of extracts of wood colonized by $\boldsymbol{H}$. fasciculare on bacteria}

Addition of wood extracts of both Hypholoma-colonized and control beech did not reduce growth of the woodinhabiting Burkholderia and Xanthomonas strains (results not shown).

\section{Discussion}

As in our previous study, there was a massive reduction in the number of bacteria in wood following colonization by $H$. fasciculare (Folman et al. 2008). The time-course analysis of bacterial dynamics and fungal decay activities performed in the present study gave some insight into the 
Fig. 4. Growth of bacteria extracted from the interior of beech wood blocks ( $100 \mathrm{mg}$ of fresh sawdust in $4 \mathrm{~mL}$ of water) in liquid media of different acidities. Bacteria were extracted from the interior of beech wood blocks after 1 month of contact between sterile blocks and forest soil (similar to $t=0$ of the time-course experiment). The liquid media were buffered at the different acidities with weak organic acids, namely citric acid (black bars) and succinic acid (grey bars). Incubation was for 1 week at $20{ }^{\circ} \mathrm{C}$. Data represent the mean and SD (error bars) of the optical density $(600 \mathrm{~nm})$ of 3 replicates of the inoculum containing the most abundant wood-inhabiting bacteria, namely 1000 -fold diluted wood extracts.

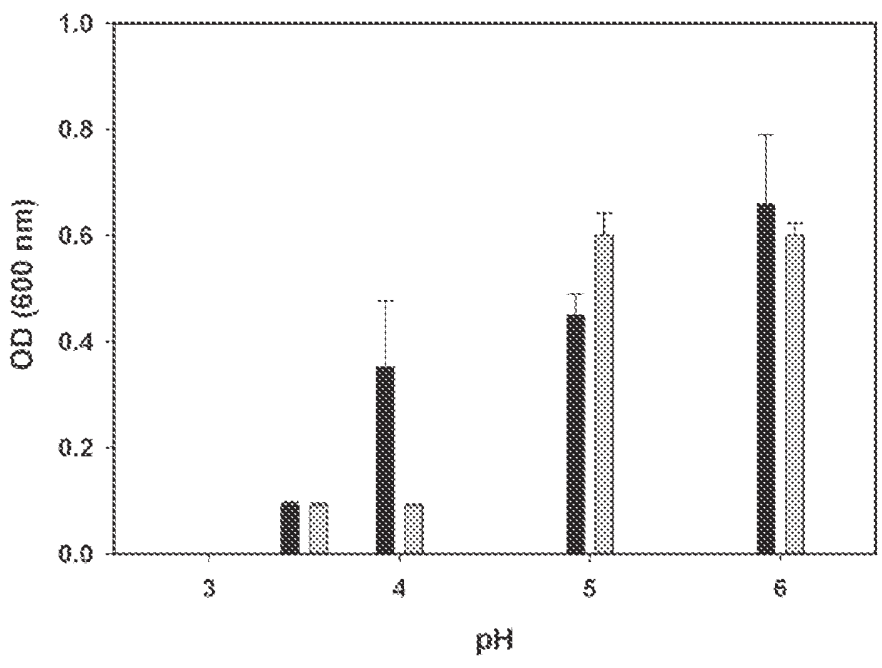

mechanisms involved in the antibacterial effect. The negative effect of $H$. fasciculare on bacteria was observed almost immediately after the start of colonization of the wood blocks. Therefore, antibacterial activities began at the same time. In the following discussion we consider the likelihood of the possible mechanisms proposed by Folman et al. (2008), based on the findings of the present study.

\section{Acidity}

The rapid and strong acidification of both beech and pine following colonization by $H$. fasciculare was not coupled to decay activities of the fungus, as wood dry mass loss and cellulase activities in pine remained low throughout the whole experiment. Rapid acidification might have been due to oxalic acid, which is produced by several white-rot fungi as well as brown-rot fungi (Mäkelä et al. 2002). Lowering of the $\mathrm{pH}$ of the environment by fungi has been indicated as a strategy to antagonize competing microbes (Rasanayagam and Jeffries 1992; Magnuson and Lasure 2004). However, although reduction in bacterial numbers was correlated with decreasing $\mathrm{pH}$ in the present study, acidity itself is not likely to explain the reduction, as the number of bacteria remained high, and even increased, in the control beech wood blocks where the $\mathrm{pH}$ had dropped, albeit slowly, to below $\mathrm{pH} 4$ by the end of the experiment. Further, in natural wood colonized by $H$. fasciculare, the number of wood-inhabiting bacteria can sometimes be high despite $\mathrm{pH}_{\text {water }}$ values as low as 3.4 (Valášková et al. 2009). Rather than acidity itself, the rate of acidification might be important; rapid acidification could prevent adaptation of bacteria to acidic conditions (De Boer et al. 1995). The inability of the dominant bacte- rial colonizers of wood blocks to grow in media at $\mathrm{pH} 3.5$ is in line with this idea.

\section{Reactive oxygen species}

Reactive oxygen species, such as hydroxyl radicals have been shown to be bactericidal (Hassett and Imlay 2007). Wood-rot fungi produce reactive oxygen species as part of the ligninolytic process, being linked to the activity of enzymes such as manganese peroxidase and laccase (Backa et al. 1993; Leonowicz et al. 1999; Shah and Nerud 2002; Mason et al. 2003). Further, hydroxyl radical production by the brown-rot fungi was shown to increase when they were exposed to bacteria (Tornberg and Olsson 2002).

Manganese peroxidase activity increased rapidly in beech wood blocks in the present study following colonization by $H$. fasciculare and coinciding with a decrease in the number of bacteria. However, by the end of the experiment, similar levels of manganese peroxidase activity were detected in the control beech wood blocks, yet there was no evidence of inhibition of bacteria. Furthermore, the number of bacteria in pine wood blocks colonized by $H$. fasciculare were strongly reduced, whereas manganese peroxidase activity was much lower than in the beech wood blocks. Therefore, the involvement of reactive oxygen species in bacterial suppression by $H$. fasciculare is not likely.

Laccase activity was only apparent in control beech wood blocks and is therefore not involved in the inhibition of bacteria by $H$. fasciculare. Laccase activity in the control may be linked to competitive interactions between fungi that have colonized these blocks from the forest soil (Baldrian 2004).

\section{Toxic secondary metabolites}

Hypholoma fasciculare is known to produce secondary metabolites with antibacterial activity (de Jong and Field 1997; Lorenzen and Anke 1998; Shiono et al. 2004). Chlorinated anisyl metabolites (CAM) have been suggested to be involved in the suppression of competing microorganisms by $H$. fasciculare in wood (de Jong and Field 1997). In natural wood samples adjacent to fruit bodies of $H$. fasciculare, CAM ranged between 24 and $180 \mathrm{mg} / \mathrm{kg}$ dry wood (de Jong et al. 1994). As the chlorine content of the CAMs produced by $H$. fasciculare is about $30 \%$, this would be equivalent to 8-60 $\mathrm{mg} \mathrm{Cl}_{\text {org }} / \mathrm{kg}$ dry wood.

The $\mathrm{Cl}_{\text {org }}$ concentrations in beech colonized by $H$. fasciculare did increase throughout the study, but only gradually from about 3 to $7 \mathrm{mg} \mathrm{Cl}$ org $/ \mathrm{kg}$ dry wood. However, the $\mathrm{Cl}_{\text {org }}$ concentrations in the control blocks increased throughout the study to levels of $60 \mathrm{mg} \mathrm{Cl} \mathrm{Cl}_{\text {org }} / \mathrm{kg}$ dry wood. Consequently, it is not likely that chlorinated antimicrobial compounds were involved in suppression of bacteria during colonization of wood blocks by $H$. fasciculare. Instead, most of the observed organochlorines in the control blocks appear to have been produced by the organisms that were suppressed by $H$. fasciculare.

Water extracts of beech wood blocks colonized by $H$. fasciculare caused no inhibition of growth of selected bacterial strains isolated from control wood blocks. However, these kinds of tests are strongly influenced by the test conditions, and a negative result does not necessarily exclude involvement of water-soluble secondary metabolites in the inhibi- 
tion. Hydrophobic compounds or volatiles could be involved in bacterial inhibition, but they would not have been present in our water extracts Volatiles are certainly produced by $H$. fasciculare, especially during competitive interactions with other white-rot fungi (Hynes et al. 2007).

\section{Other possibilities}

Ergosterol levels inside the wood blocks remained low during the whole incubation period, indicating that $\mathrm{H}$. fasciculare is mainly present in the outer region of the wood during this colonization phase, agreeing with observations of naturally colonized wood incubated in a damp atmosphere (L. Boddy, pers. observ.). Apparently, the colonizing strategy of $H$. fasciculare is to form a dense hyphal network on the outside of the wood blocks and to release enzymes and organic acids to the inside. In addition, anaerobic conditions could be created inside the wood blocks by the active dense mycelium on the outside, preventing oxygen penetration into the wood and escape of carbon dioxide and inhibitory volatiles from the wood. The large increase in manganese peroxidase activity inside beech wood blocks might also have contributed to depletion of oxygen (Khindaria et al. 1994).

\section{Conclusions}

Successful colonization of wood by $H$. fasciculare coincided with inhibition of opportunistic wood-inhabiting bacteria and fungi (Folman et al. 2008). Suppressing opportunistic wood-inhabiting microorganisms will also remove the threat of competition for products of wood decomposition and provides nutrients, including nitrogen (Barron 1988). Our results indicate that rapid acidification might be an important factor in the inhibition of bacteria. Though there was no evidence that secondary metabolites or reactive oxygen species are important in overall reduction in bacterial numbers, their involvement cannot be completely excluded.

\section{Acknowledgements}

We thank Marcel Govaert, who contributed to this research as part of his M.Sc. study at Wageningen University. We wish to express our thanks to Wiecher Smant, who performed analyses of enzyme activities and ergosterol content. This is publication No. 4694 of the Netherlands Institute of Ecology (NIOO-KNAW).

\section{References}

Asplund, G., Grimvall, A., and Jonsson, S. 1994. Determination of the total and leachable amounts of organohalogens in soil. Chemosphere, 28(8): 1467-1475. doi:10.1016/0045-6535(94)902410 .

Bååth, E. 2001. Estimation of fungal growth rates in soil using ${ }^{14} \mathrm{C}-$ acetate incorporation into ergosterol. Soil Biol. Biochem. 33(14): 2011-2018. doi:10.1016/S0038-0717(01)00137-7.

Backa, S., Gierer, J., Reitberger, T., and Nilsson, T. 1993. Hydroxyl radical activity associated with the growth of white-rot fungi. Holzforschung, 47(3): 181-187. doi:10.1515/hfsg.1993. 47.3.181.

Baldrian, P. 2004. Increase of laccase activity during interspecific interactions of white-rot fungi. FEMS Microbiol. Ecol. 50(3): 245-253. doi:10.1016/j.femsec.2004.07.005. PMID:19712364.

Baldrian, P. 2008. Enzymes of saprotrophic basidiomycetes. In
Ecology of saprotrophic basidiomycetes. Edited by L. Boddy, J.C. Frankland, and P. van West. Academic Press, Oxford, UK. pp. 19-41.

Barron, G.L. 1988. Microcolonies of bacteria as nutrient source for lignicolous and other fungi. Can. J. Bot. 66(12): 2505-2510.

Boddy, L. 1999. Saprotrophic cord-forming fungi: meeting the challenge of heterogenous environments. Mycologia, 91(1): 1332. doi:10.2307/3761190.

Bourbonnais, R., and Paice, M.G. 1990. Oxidation of non-phenolic substrates. An expanded role for laccase in lignin biodegradation. FEBS Lett. 267(1): 99-102. doi:10.1016/0014-5793(90) 80298-W. PMID:2365094.

Daniel, G., Volc, J., and Kubatova, E. 1994. Pyranose oxidase: a major source of $\mathrm{H}_{2} \mathrm{O}_{2}$ during wood degradation by Phanerochaete chrysosporium, Trametes versicolor, and Oudemansiellla mucida. Appl. Environ. Microbiol. 60(7): 2524-2532. PMID: 16349330.

De Boer, W., and van der Wal, A. 2008. Interactions between saprotrophic basidiomycetes and bacteria. Edited by L. Boddy, J.C. Frankland, and P. van West. Academic Press, Oxford, UK. pp. 143-153.

De Boer, W., Klein Gunnewiek, P.J.A., and Laanbroek, H.J. 1995. Ammonium oxidation at low $\mathrm{pH}$ by a chemolithotrophic bacterium belonging to the genus Nitrosospira. Soil Biol. Biochem. 27(2): 127-132. doi:10.1016/0038-0717(94)00157-V.

De Jong, E., and Field, J.A. 1997. Sulfur tuft and turkey tail: biosynthesis and biodegradation of organohalogens by Basidiomycetes. Annu. Rev. Microbiol. 51(1): 375-414. doi:10.1146/ annurev.micro.51.1.375. PMID:9343355.

De Jong, E., Field, J.A., Spinnler, H.-E., Wijnberg, J.B.P.A., and de Bont, J.A.M. 1994. Significant biogenesis of chlorinated aromatics by fungi in natural environments. Appl. Environ. Microbiol. 60(1): 264-270. PMID:16349156.

De Ridder-Duine, A.S., Smant, W., van der Wal, A., van Veen, J.A., and de Boer, W. 2006. Evaluation of a simple, non-alkaline extraction protocol to quantify soil ergosterol. Pedobiologia (Jena), 50(4): 293-300. doi:10.1016/j.pedobi.2006.03.004.

Faix, O., Meier, D., and Fortmann, I. 1990. Thermal degradation products of wood. A collection of electron-impact (EI) mass spectra of monomeric lignin derived products. Holz Roh Werkstoff, 48(9): 351-354. doi:10.1007/BF02639897.

Folman, L.B., Klein Gunnewiek, P.J.A., Boddy, L., and de Boer, W. 2008. Impact of white-rot fungi on numbers and community composition of bacteria colonizing beech wood from forest soil. FEMS Microbiol. Ecol. 63(2): 181-191. doi:10.1111/j.15746941.2007.00425.x. PMID:18199083.

Hassett, D.J., and Imlay, J.A. 2007. Bactericidal antibiotics and oxidative stress: a radical proposal. ACS Chem. Biol. 2(11): 708-710. doi:10.1021/cb700232k. PMID:18030985.

Hynes, J., Müller, C.T., Jones, T.H., and Boddy, L. 2007. Changes in volatile production during the course of fungal mycelial interactions between Hypholoma fasciculare and Resinicium bicolor. J. Chem. Ecol. 33(1): 43-57. doi:10.1007/s10886-006-9209-6. PMID: 17146718.

Khindaria, A., Grover, T.A., and Aust, S.D. 1994. Oxalatedependent reductive activity of manganese peroxidase from Phanerochaete chrysosporium. Arch. Biochem. Biophys. 314(2): 301-306. doi:10.1006/abbi.1994.1446. PMID:7979369.

Leonowicz, A., Matuszewska, A., Luterek, J., Ziegenhagen, D., Wojtaś-Wasilewska, M., Cho, N.S., et al. 1999. Biodegradation of lignin by white rot fungi. Fungal Genet. Biol. 27(2-3): 175185. doi:10.1006/fgbi.1999.1150. PMID:10441443.

Lorenzen, K., and Anke, T. 1998. Basidiomycetes as a source for new bioactive natural products. Curr. Org. Chem. 2(4): 329-364. 
Magnuson, J.K., and Lasure, L.L. 2004. Organic acid production by filamentous fungi. Edited by J.S. Tkacz and L. Lange. Advances in fungal biotechnology for industry, agriculture and medicine. Kluwer Academic/Plenum Publishers, New York, NY. pp. 307340.

Mäkelä, M., Galkin, S., Hatakka, A., and Lundell, T. 2002. Production of organic acids and oxalate decarboxylase in lignindegrading white rot fungi. Enzyme Microb. Technol. 30(4): 542-549. doi:10.1016/S0141-0229(02)00012-1.

Mason, M.G., Nicholls, P., and Wilson, M.T. 2003. Rotting by radicals - the role of cellobiose oxidoreductase? Biochem. Soc. Trans. 31(6): 1335-1336. doi:10.1042/BST0311335. PMID: 14641057.

Ralph, J., and Hatfield, R.D. 1991. Pyrolysis-GC/M.S. characterization of forage materials. J. Agric. Food Chem. 39(8): 14261437. doi:10.1021/jf00008a014.

Rasanayagam, S., and Jeffries, P. 1992. Production of acid is responsible for antibiosis by some ectomycorrhizal fungi. Mycol. Res. 96(11): 971-976. doi:10.1016/S0953-7562(09)80600-X.

Schmidt, O. 2006. Wood and tree fungi: biology, damage, protection, and use. Springer-Verlag, Berlin, Germany.

Schwarze, F.W.M.R., Engels, J., and Mattheck, C. 2000. Fungal strategies of wood decay in trees. Springer-Verlag, Berlin, Germany.
Shah, V., and Nerud, F. 2002. Lignin degrading system of whiterot fungi and its exploitation for dye decolorization. Can. J. Microbiol. 48(10): 857-870. doi:10.1139/w02-090. PMID: 12489775.

Shiono, Y., Matsuzaka, R., Wakamatsu, H., Muneta, K., Murayama, T., and Ikeda, M. 2004. Fascicularones A and B from a mycelial culture of Naematoloma fasciculare. Phytochemistry, 65(4): 491-496. doi:10.1016/j.phytochem.2003.10. 002. PMID: 14759547.

Tornberg, K., and Olsson, S. 2002. Detection of hydroxyl radicals produced by wood-decomposing fungi. FEMS Microbiol. Ecol. 40(1): 13-20. doi:10.1111/j.1574-6941.2002.tb00931.x. PMID: 19709206.

Valášková, V., de Boer, W., Klein Gunnewiek, P.J.A., Pospíšek, M., and Baldrian, P. 2009. Phylogenetic composition and properties of bacteria coexisting with the fungus Hypholoma fasciculare in decaying wood. ISME J. 3(10): 1218-1221. doi:10.1038/ ismej.2009.64. PMID:19516282.

Van der Wal, A., de Boer, W., Smant, W., and van Veen, J.A. 2007. Initial decay of woody fragments in soil is influenced by size, vertical position, nitrogen availability and soil origin. Plant Soil, 301(1-2): 189-201. 